\title{
COMPARATIVE ASSESSMENT OF REMINERALIZING POTENTIAL OF RECENT BIOMIMETIC REMINERALIZING AGENTS ON SUB-SURFACE CARIOUS LESIONS: AN IN VITRO STUDY
}

\author{
Walaa Mohamed Alsamolly*
}

\begin{abstract}
Introduction: Enamel demineralization and remineralization are considered dynamic and continuous process that occurs throughout the life. Subsurface caries is distinct when the amount of subsurface minerals missed go above the amount of minerals secured. The biomimetic remineralizing protocol is planned to encourage maximum maintenance of healthy dental hard tissues in subsurface stage.
\end{abstract}

Aim: Directed to assess the remineralizing potential of self-assembling peptide P11-4, phosphorylated chitosan and nano hydroxyapatite paste on subsurface carious lesions.

Materials and methods: Forty sound non-carious human anterior teeth were used. The teeth were divided into four groups (10 teeth each). Group A1: specimens were stored in artificial saliva; Group A2: using Curodont repair; Group A3 using phosphorylated chitosan and; Group A4: using nanohydroxyapatite paste. All products were applied according to the manufacturer's instructions and each group was subdivided into two groups according to the storage time group B1: 3 months and group B2: 6 months.

Calcium and phosphorous weight and ratio were assessed using dispersive X-ray energy and Diagnodent pen at base line then after 3 and 6months. The mean and standard deviation values were calculated for each group in each test.

Results: Specimens treated with Curodont repair after six months record the highest mean value while the lowest mean value was found in artificial saliva, also for all remineralizing agents (Curodont repair, phosphorylated chitosan, and Nanohydroxyapatite paste) and control group the remineralization potential was increased by increasing the storage time (three month and six months).

Conclusion: Curodont repair is considered a valuable biomimetic remineralizing agent.

KEYWORDS: Remineralization, Chitosan, self-assembling peptide P11-4, Nanohydroxyapatite paste.

\footnotetext{
* Lecturer of Operative Dentistry, Faculty of Dentistry, Al-Azhar University (Boys) Cairo.
} 


\section{INTRODUCTION}

Dental caries, a disease affecting hard dental tissues, is still considered a most important oral health challenge. Sub-surface carious lesions or white spot lesions are probably considered as early indication of dental caries disease. Modern dentistry advocates the noninvasive style for the management of non-cavitated, subsurface lesions via remineralization. Through remineralization, these lesions can be backed noninvasively without following the conventional method of drilling and filling. ${ }^{(1,2)}$

The conventional remineralization is the procedure whereby calcium and phosphate ions are precipitated from external source to the tooth surface in order to promote ion deposition into the crystal voids of demineralized enamel to facilitate mineral gain. ${ }^{(3)}$

Biomimetic remineralization is approach that mimics the natural process of mineralization by simulating the bio mineralization process. Several remineralizing agents are now present, these agents initiate remineralization by forming three dimensional structures mimic extracellular matrix of teeth. ${ }^{(4)}$

The modern self-assembling peptide $\left(\mathrm{P}_{11}-4\right)$ is applicant for enamel regeneration approach. $\mathrm{P}_{11}$ 4 is a rationally planned $\beta$-sheet- shaping peptide that under certain ecological triggers, self- gathers into three-dimensional fibrillar platforms and imitates the action of the extracellular enamel matrix proteins acquired during tooth development. Consequently, it restates histogenesis, by pulling in, authoritative and settling calcium particles initiating anew hydroxyapatite precipitation. ${ }^{(5)}$

Curodont Repair technology offers monomeric self-assembling peptides (P11-4), which diffuses into the subsurface of WSL and self-collects into 3D fibrillar platforms. The gathered P11-4 platform is able to promoting anew hydroxyapatite crystal nucleation and supports mineral crystal development in a cycle of biomimetic mineralization. It is qualified to restore enamel using a procedure that is equivalent to the enamel matrix during enamel formation process. ${ }^{(6)}$

The protective effect of self- assembling peptide (P11-4) (Curodont repair) and its value in rehardening white spot lesion (WSL) produced by different acidic fluids within the oral cavity takes place for more research in dental field. ${ }^{(7)}$

Chitosan is a linear co-polymer of glucosamine. Its subordinates have risen as another class of novel biomaterials because of their adaptable biological activity, fantastic biocompatibility and complete biodegradability. ${ }^{(8)}$

So, Chitosan has been established wide application in biomedical fields, such as drug delivery, wound dressing, as a tissue replacement material. ${ }^{(9)}$

Free phosphorylated chitosan (Pchi) molecules demonstrated the inhibitory activity on the formation of calcium phosphate deposits in solution. Thus, Pchi could be applied to settle ACP to form the nano-complexes of Pchi-ACP for remineralizing enamel subsurface lesion based on the biomimetic policy. ${ }^{(10)}$

Synthetic nano-hydroxyapatite (Nano-HA) is an attractive biomaterial due to its chemical and structural resemblance with natural tooth mineral. It has been recommended that the Nano-HA would prompt an extensively prevalent remineralization. ${ }^{(11)}$

Biomimetic effect of the nano-hydroxyapatite depends on its connection with organic tissues and on its capacity to copy biogenic materials in their functionalities. There chemical composition is analogous to enamel and dentin, with intermediary characteristics. Gradual action of biomimetic nano hydroxyapatite crystals permits the bond to dentinal and enamel tooth surfaces due to bio-reabsorption properties under physiological conditions. This property can be adjusted by ion substitution and 
crystallinity degree achieved implementing novel synthesis with nano sized crystal control. ${ }^{(12,13)}$

Therefore, the present study aimed to evaluate and compare the degree of demineralization and remineralization in sub-clinical carious lesion using different biomimetic remineralizing agent.

Under the following variables:

1- Biomimetic remineralizing agent:

1.1 Phosphorylated Chitosan (Pchi).

1.2 Self-assembling peptide P11-4"curodent repair".

1.3 Nano hydroxyapatite paste.

2- Different storage times:

2.1 Three months storage time.

2.2 Six months storage time.

\section{MATERIALS AND METHODS}

\section{I- Materials:}

The following materials were used in this study (table 1)

TABLE (1): Materials used in the study:
1. Demineralizing solution containing $(1.5 \mathrm{mM}$ $\mathrm{CaCl} 2,0.9 \mathrm{mM} \mathrm{KH} 2 \mathrm{PO} 4,50 \mathrm{mM} \mathrm{CH} 3 \mathrm{COOH}$, and $3 \mathrm{mM} \mathrm{NaN3}$ ) with $\mathrm{pH} 4.8$

2. Chitosan in the form of phosphorylated chitosan and amorphous calcium phosphate (Pchi-ACP) as a remineralizing agent.

3. Self-assembling peptide P11-4 in the form of Curodont repair paste as a remineralizing agent.

4. Nanohydroxyapatite paste as a remineralizing agent.

5. Artificial saliva solution was prepared in Faculty of Pharmacy, Al-Azhar University. consisting of $\left(0.4 \mathrm{~g} \mathrm{NaCl}, 0.4 \mathrm{~g} \mathrm{KCl}, 0,6 \mathrm{~g} \mathrm{CaCl}_{2}, 0.6 \mathrm{~g}\right.$ $\mathrm{NaH}_{2} \mathrm{PO}_{4}, 4$ g Urea, $4 \mathrm{~g}$ Mucin, $0.0016 \mathrm{~g} \mathrm{Na}_{2} \mathrm{~S}$, $0.0016 \mathrm{~g} \mathrm{Mg}_{2} \mathrm{P}_{2} \mathrm{O}_{7}+1 \mathrm{~L}$ distilled water) at $\mathrm{pH} 7$

\section{Selection and grouping of teeth:}

A total number of 40 sound non-carious human anterior teeth were gathered from oral surgery clinic, liberated from cracks and any formative deformities, were used in this investigation in age range (20-40) years of age. The teeth were washed under running water to eliminate blood and debris, scaled to

\begin{tabular}{|c|c|c|c|}
\hline & Material & Composition & Manufacture \&website \\
\hline 1 & $\begin{array}{l}\text { phosphorylated } \\
\text { chitosan and amorphous } \\
\text { calcium phosphate } \\
\text { (Pchi-ACP) }\end{array}$ & $\begin{array}{l}\text { (Pchi-ACP) prepared by adding } \mathrm{CaCl} 2 \text { and } \mathrm{K} 2 \mathrm{HPO} 4 \\
\text { into Pchi-ACP solution }(0.5 \% \mathrm{w} / \mathrm{v}) \text { in sequence. The } \\
\text { final concentrations of calcium and phosphate ions } \\
\text { were } 10 \text { and } 6 \mathrm{mM} \text {, respectively }\end{array}$ & $\begin{array}{l}\text { Oxford laboratory reagent } \\
\text { www.oxfordlabchem.com }\end{array}$ \\
\hline 2 & Curodont Repair & $\begin{array}{l}\text { Curodont }{ }^{\mathrm{TM}} \text { Repair contains the self-assembling } \\
\text { peptide P11-4 that diffuses deeply into the subsurface } \\
\text { body of the carious lesion. } \\
\mathrm{Ca} 2+\text { and PO4 ions, the components of enamel, are } \\
\text { sufficiently available from the patients' saliva and } \\
\text { attach to the matrix, inducing de-novo formation of } \\
\text { hydroxyapatite (HAP) crystals. }\end{array}$ & $\begin{array}{l}\text { Mectron Deutschland Vertriebs } \\
\text { GmbH, Cologne, Germany }\end{array}$ \\
\hline 3 & $\begin{array}{l}\text { Nano hydroxyapatite } \\
\text { paste }\end{array}$ & $\begin{array}{l}\text { Rod-like hydroxyapatite particles (diameter }<100 \mathrm{~nm} \text {, } \\
\text { aspect ratio } 2-3 \text { ) }\end{array}$ & $\begin{array}{c}\text { (Nano Streams - 6th October } \\
\text { city-Egypt) } \\
\text { nanostreams.co.uk }\end{array}$ \\
\hline
\end{tabular}


remove calculus and remnants of periodontal tissue and polished with eugenol free fine pumice and soft rubber cups rotating at low speed under water coolant. Teeth were put away in distilled water at room temperature until use. The distilled water was changed day by day.

The teeth were divided into four main (A) groups $(\mathrm{N}=10)$ according to the remineralizing agent:

Group A1: specimens were stored in artificial saliva (control).

Group A2: Teeth were treated using selfassembling peptide P11-4 in the form of Curodont repair paste as a remineralizing agent.

Group A3: Teeth were treated using phosphorylated Chitosan (Pchi).

Group A4: Teeth were treated by Nanohydroxyapatite paste as a remineralizing agent.

Each main group was further subdivided into two groups $(B)\left(N_{=} 5\right)$ according to the storage time in the artificial saliva:

(B1): teeth will be evaluated after 3 months (3M) storage time.

(B2): teeth will be evaluated after 6 months $(6 \mathrm{M})$ storage time.

\section{I- Preparation of specimens}

The crowns of recently extracted forty intact human anterior teeth were separated from the roots by a diamond-coated band saw under continuous water cooling, then stored in artificial saliva until used.

\section{A- Fabrications of the mold:}

A specially fabricated circle plastic mold of internal diameter $10 \mathrm{~mm}$ and $20 \mathrm{~mm}$ in height was fabricated.

A separating medium was used to coat the internal surface of the mold.
The mold was filled with self-curing acrylic resin, the base of the mold rested on a glass slab in order to obtain a flat smooth surface base.

Each crown was inserted horizontally in middle of the mold contain self-cure acrylic resin in dough stage while the lingual surface inserted in resin and leaving about two $\mathrm{mm}$ from the labial surface protruding above the surface of the mold using caliber fig (1).

Then paint the labial surface of all the teeth with nail varnish ${ }^{\$}$ except three $\mathrm{mm}$ square in the middle of the crown (mesiodistally and cervicoincisally).

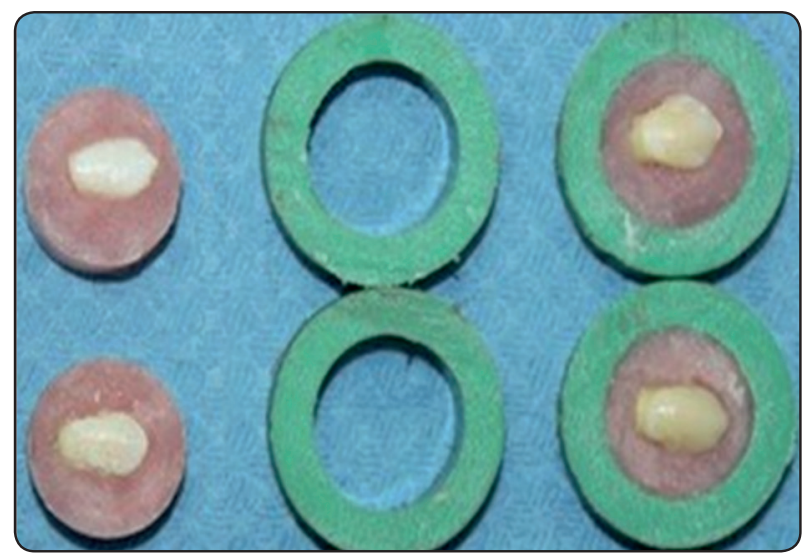

Fig. (1): Crowns were embedded horizontally in middle of the mold.

\section{B-Enamel White spot Lesion formation}

The labial surface of each specimens is treated by the demineralizing solution with $\mathrm{pH} 4.8$. The teeth immersed into that solution (one sample/30 mL) for 7 days at $37 \mathrm{C}$ in a shaker (50 rpm) to prepare enamel subsurface lesion.

\section{C-Surface treatments}

In group (A1): 10 specimens were immersed in artificial saliva changed daily.

In group (A2): The labial surfaces of 10 specimens were brushed manually with minimum pressure; brushing procedures were carried out three times daily with Curodont repair the stick of Curodont repair solution is pushed in firstly and then 
pulled out with its wetted sponge head then gentle application of Curodont Repair for 5 minutes.

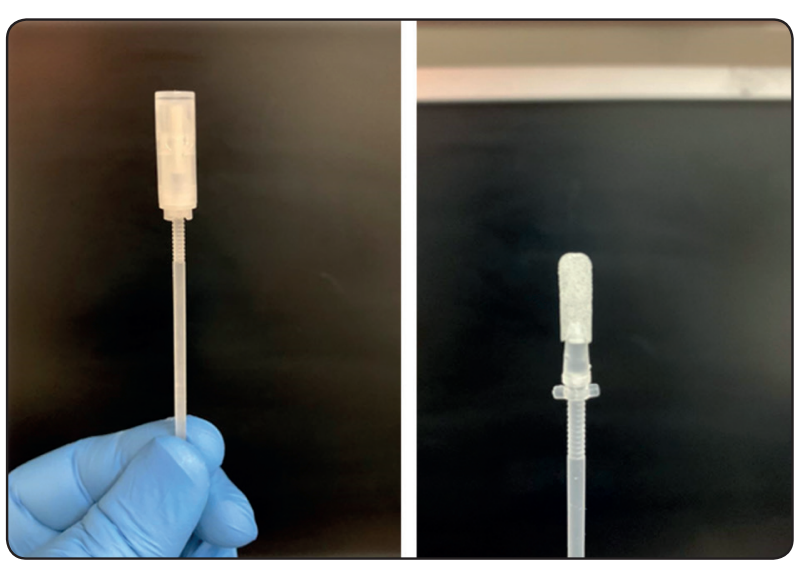

Fig. (2): stick of Curodont repair solution is pushed in firstly and then pulled out with its wetted sponge head

In group (A3): The labial surfaces of 10 specimens were brushed manually by a soft toothbrush and with minimum pressure; brushing procedures were carried out for three minutes three times daily with a phosphorylated chitosan and amorphous calcium phosphate (Pchi-ACP).

In group (A4): The labial surfaces of 10 specimens were brushed manually by a disposable soft micro-brush and with minimum pressure; brushing procedures were carried out for one minute by a quantity of nano-HA paste result from HA mixed with distilled water in a ratio of $2 \mathrm{~g}$ powder to $1 \mathrm{ml}$ liquid, followed by copious rinsing with distilled water for one minute then immersed in artificial saliva.

These forty samples were evaluated at base line after demineralization then after 3 and 6months storage time using Energy Dispersive X-Ray (EDX) and Diagnodent pen 2190.

\section{Mineral content assessment:}

40 specimens (10 untreated, 10 treated by Curodont repair, 10 treated by phosphorylated chitosan amorphous calcium phosphate (Pchi-ACP) and 10 treated by Nanohydroxyapatite paste), were subjected to surface analysis (for minerals presence or absence and their percentage, especially calcium and phosphorus) by Energy Dispersive X-Ray (EDX) and Diagnodent pen. EDX spectrum images were acquired with an EMiSPEC vision integrated acquisition system. Data was recorded within an average of 6 minutes for each specimen.

\section{Statistical analysis:}

The mean and standard deviation values were calculated for each group in each test. Data were explored for normality using Kolmogorov-Smirnov and Shapiro-Wilk tests, data showed parametric (normal) distribution. One-way ANOVA followed by Tukey post hoc test was used to compare between more than two groups in non-related samples. Paired sample t-test was used to compare between two groups in related samples. Two-way ANOVA was used to test the interaction between variables. The significance level was set at $\mathrm{P} \leq$ 0.05 . Statistical analysis was performed with IBM ${ }^{\circledR}$ SPSS $\circledR^{\circ}$ Statistics Version 20 for Windows.

\section{RESULTS}

\section{Effect of remineralizing agent on the degree of remineralization assessment by EDX:}

\section{Degree of remineralization at control group:}

The highest mean value for control (64.68 \pm 1.97) was recorded for calcium precipitation after six months storage time while the lowest men value $(1.15 \pm 0.15)$ recorded for $\mathrm{ca} / \mathrm{p}$ ratio at base line. There was significant increase $(\mathrm{p}<0.001)$ in calcium precipitation $(61.93 \pm 0.62$ and $64.68 \pm 1.97)$ to tooth structure by increased the storage times (three months and six months). While there was significant decrease $(\mathrm{p}<0.001)$ in phosphorus precipitation $(40.07 \pm 0.62$ and $37.32 \pm 1.97)$ to tooth structure by increased the storage times (three months and six months). There was s ignificant increase $(\mathrm{p}<0.001)$ in calcium phosphorus ratio $(\mathrm{ca} / \mathrm{p})$ precipitation $(1.54$ \pm 0.04 and $1.73 \pm 0.16$ ) to tooth structure by increased the storage times (three months and six months). 


\section{Degree of remineralization at Curodont repair group}

Calcium precipitation after Curodont repair application of six months storage time showed the highest mean value $(80.28 \pm 1.28)$ while ca/p ratio record the lowest mean value $(1.47 \pm 0.09)$ at base line . By increasing the storage times (three months and six months) there was significant increase $(\mathrm{p}<0.001)$ in calcium precipitation $(71.99 \pm 1.53$ and 80.28 \pm 1.57 ) to tooth structure. Phosphorus precipitation $(30.00 \pm 1.53$ and $21.72 \pm 1.57)$ to tooth structure significantly decrease $(\mathrm{p}<0.001)$ by increasing in storage times (three months and six months). By increasing the storage times (three months and six months) there was significant increase $(p<0.001)$ in calcium phosphorus ratio (ca/p) $(2.39 \pm 0.20$ and 3.69 \pm 0.40 ) precipitation to tooth structure.

TABLE (2) The mean, standard deviation (SD) values of Control group on mineral precipitation at different storage time.

\begin{tabular}{|c|c|c|c|c|c|c|c|}
\hline \multirow{3}{*}{ Variables } & \multicolumn{7}{|c|}{ Control } \\
\hline & \multicolumn{2}{|c|}{ Baseline } & \multicolumn{2}{|c|}{ After 3m } & \multicolumn{2}{|c|}{ After $6 \mathrm{~m}$} & \multirow{2}{*}{ p-value } \\
\hline & Mean & SD & Mean & SD & Mean & SD & \\
\hline $\mathrm{Ca}$ & $54.72^{\mathrm{c}}$ & 3.11 & $61.93^{\mathrm{b}}$ & 0.62 & $64.68^{a}$ & 1.97 & $<0.001 *$ \\
\hline $\mathbf{P}$ & $47.28^{\mathrm{a}}$ & 3.11 & $40.07^{\mathrm{b}}$ & 0.62 & $37.32^{\mathrm{c}}$ & 1.97 & $<0.001 *$ \\
\hline $\mathrm{Ca} / \mathbf{P}$ & $1.15^{\mathrm{c}}$ & 0.15 & $1.54^{\mathrm{b}}$ & 0.04 & $1.73^{\mathrm{a}}$ & 0.16 & $<0.001 *$ \\
\hline
\end{tabular}

Means with different letters in same raw indicate significant difference $(p<0.05)$

TABLE (3) The mean, standard deviation (SD) values of Curodont repair of remineralizing agents on mineral precipitation at different storage time.

\begin{tabular}{|l|c|c|c|c|c|c|c|}
\hline \multirow{3}{*}{ Variables } & \multicolumn{7}{|c|}{ Curodont repair } \\
\cline { 2 - 8 } & \multicolumn{2}{|c|}{ Baseline } & \multicolumn{2}{c|}{ After 3m } & \multicolumn{2}{c|}{ After 6m } & \multirow{2}{*}{ p-value } \\
\cline { 2 - 8 } & Mean & SD & Mean & SD & Mean & SD & \\
\hline $\mathbf{C a}$ & $60.72^{\mathrm{c}}$ & 2.29 & $71.99^{\mathrm{b}}$ & 1.53 & $80.28^{\mathrm{a}}$ & 1.57 & $<\mathbf{0 . 0 0 1 *}$ \\
\hline $\mathbf{P}$ & $41.28^{\mathrm{a}}$ & 2.29 & $30.00^{\mathrm{b}}$ & 1.53 & $21.72^{\mathrm{c}}$ & 1.57 & $<\mathbf{0 . 0 0 1 *}$ \\
\hline $\mathbf{C a} / \mathbf{P}$ & $1.47^{\mathrm{c}}$ & 0.09 & $2.39^{\mathrm{b}}$ & 0.20 & $3.69^{\mathrm{a}}$ & 0.40 & $<\mathbf{0 . 0 0 1 *}$ \\
\hline
\end{tabular}

Means with different letters in same raw indicate significant difference $(p<0.05)$
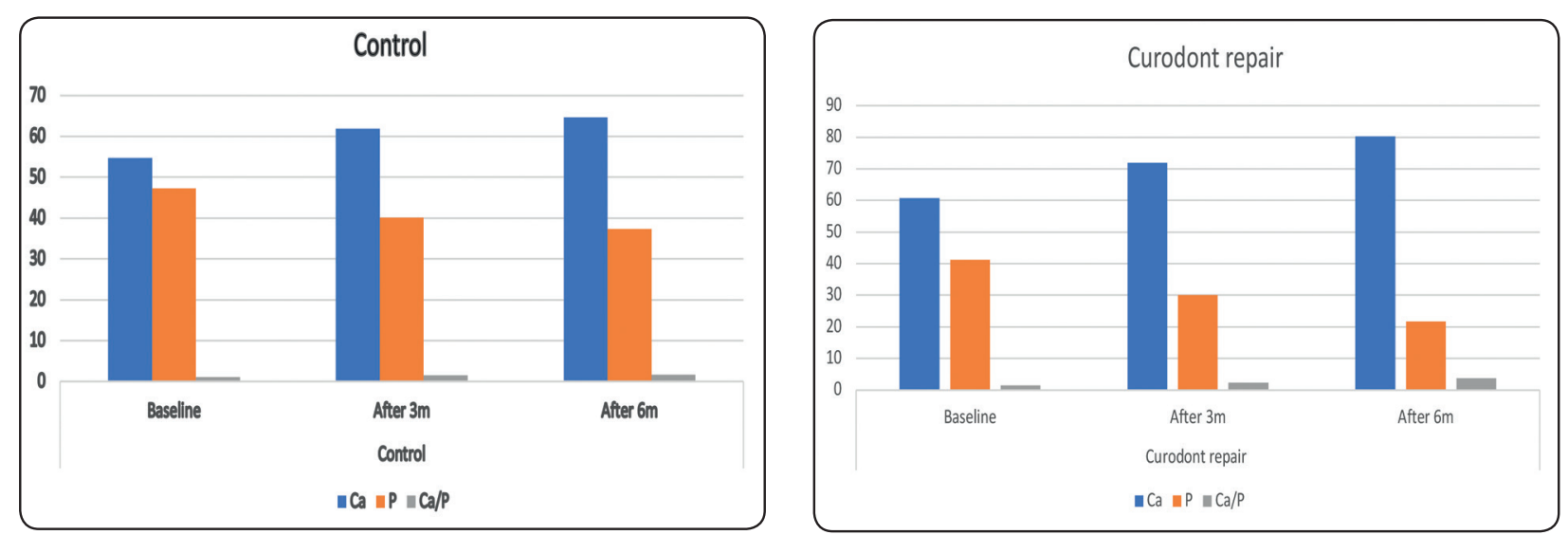


\section{Degree of remineralization at Chitosan group}

Calcium precipitation after Chitosan application showed the highest mean value $(75.86 \pm 1.97)$ at six-month storage time while the $\mathrm{ca} / \mathrm{p}$ ratio at base line showed the lowest value $(1.42 \pm 0.14)$. There was significant increase $(\mathrm{p}<0.001)$ in calcium precipitation $(71.30 \pm 1.72$ and $75.86 \pm 1.97)$ to tooth structure by increased the storage time (three months and six months). While there was significant decrease $(\mathrm{p}<0.001)$ in phosphorus precipitation $(30.50 \pm 1.86$ and $26.14 \pm 1.97)$ to tooth structure by increased the storage time (three months and six months). There was significant increase $(\mathrm{p}<0.001)$ in calcium phosphorus ratio $(\mathrm{ca} / \mathrm{p})$ precipitation $(2.33 \pm 0.17$ and $2.90 \pm 0.32)$ to tooth structure by increased the storage times (three months and six months).

TABLE (4) The mean, standard deviation (SD) values of Chitosan of remineralizing agents on mineral precipitation at different storing time.

\begin{tabular}{|c|c|c|c|c|c|c|c|}
\hline \multirow{3}{*}{ Variables } & \multicolumn{7}{|c|}{ Chitosan } \\
\hline & \multicolumn{2}{|c|}{ Baseline } & \multicolumn{2}{|c|}{ After 3m } & \multicolumn{2}{|c|}{ After $6 \mathrm{~m}$} & \multirow[t]{2}{*}{ p-value } \\
\hline & Mean & SD & Mean & SD & Mean & SD & \\
\hline $\mathrm{Ca}$ & $59.96^{c}$ & 2.61 & $71.30^{\mathrm{b}}$ & 1.72 & $75.86^{\mathrm{a}}$ & 1.97 & $<0.001 *$ \\
\hline $\mathbf{P}$ & $42.04^{\mathrm{a}}$ & 2.61 & $30.50^{\mathrm{b}}$ & 1.86 & $26.14^{\mathrm{c}}$ & 1.97 & $<0.001 *$ \\
\hline $\mathrm{Ca} / \mathbf{P}$ & $1.42^{\mathrm{c}}$ & 0.14 & $2.33^{b}$ & 0.17 & $2.90^{\mathrm{a}}$ & 0.32 & $<0.001 *$ \\
\hline
\end{tabular}

Means with different letters in same raw indicate significant difference $(p<0.05)$

TABLE (5) The mean, standard deviation (SD) values of Nanohydroxyapatite paste of remineralizing agents on mineral precipitation at different storing time.

\begin{tabular}{|l|c|c|c|c|c|c|c|}
\hline \multirow{3}{*}{ Variables } & \multicolumn{7}{|c|}{ Nanohydroxyapatite paste } \\
\cline { 2 - 8 } & \multicolumn{2}{|c|}{ Baseline } & \multicolumn{2}{c|}{ After 3m } & \multicolumn{2}{c|}{ After $\mathbf{6 m}$} & \multirow{2}{*}{ p-value } \\
\cline { 2 - 8 } & Mean & SD & Mean & SD & Mean & SD & $<$ \\
\hline $\mathbf{C a}$ & $56.86^{\mathrm{c}}$ & 2.86 & $69.40^{\mathrm{b}}$ & 1.86 & $70.21^{\mathrm{a}}$ & 1.15 & $<\mathbf{0 . 0 0 1 *}$ \\
\hline $\mathbf{P}$ & $45.14^{\mathrm{a}}$ & 2.86 & $32.60^{\mathrm{b}}$ & 1.86 & $31.81^{\mathrm{c}}$ & 1.13 & $<\mathbf{0 . 0 0 1 *}$ \\
\hline $\mathbf{C a} / \mathbf{P}$ & $1.25^{\mathrm{c}}$ & 0.15 & $2.12^{\mathrm{b}}$ & 0.17 & $2.20^{\mathrm{a}}$ & 0.13 & $<\mathbf{0 . 0 0 1 *}$ \\
\hline
\end{tabular}

Means with different letters in same raw indicate significant difference $(p<0.05)$
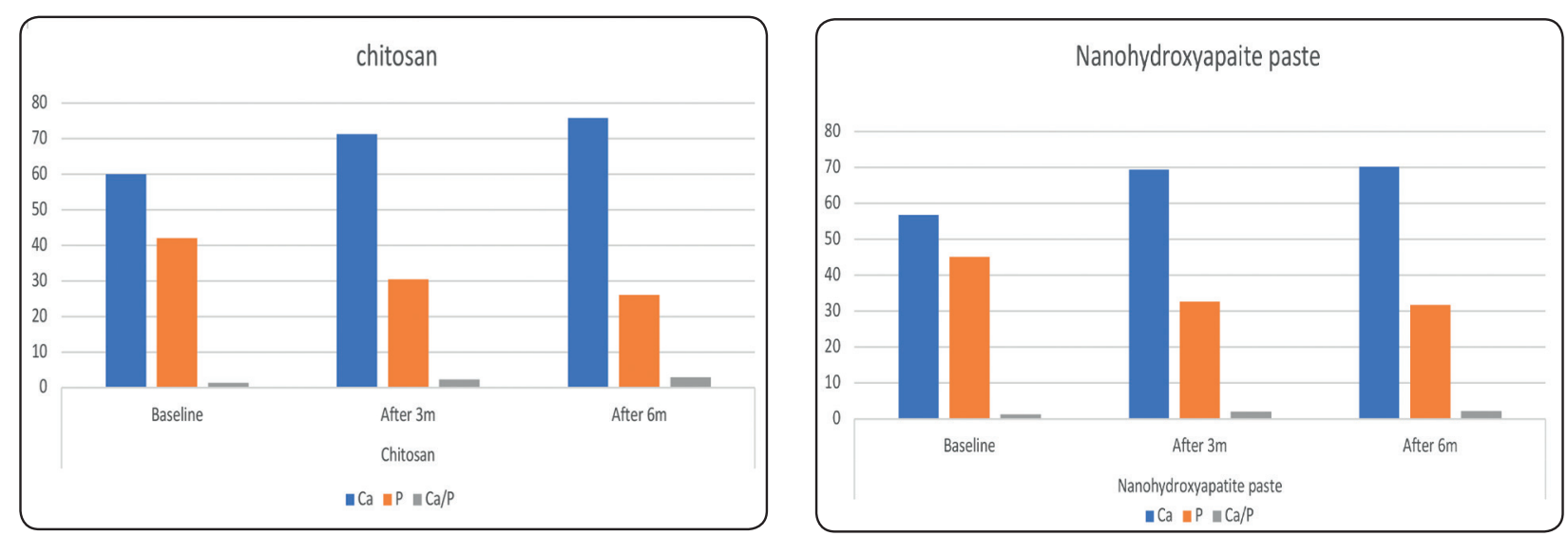


\section{Degree of remineralization at Nanohydroxyapatite powder group:}

The highest mean value $(70.21 \pm 1.15)$ was recorded for calcium precipitation after application of Nanohydroxyapatite paste for six months storage time while the lowest men value $(1.25 \pm 0.15)$ recorded for $\mathrm{ca} / \mathrm{p}$ ratio at base line. By increasing the storage times (three months and six months) there was significant increase $(\mathrm{p}<0.001)$ in calcium precipitation $(69.40 \pm 1.86$ and $70.21 \pm 1.15)$ to tooth structure.

Phosphorus precipitation $(32.60 \pm 1.86$ and $31.81 \pm 1.13)$ to tooth structure significantly decrease $(p<0.001)$ by increasing in storage times (three months and six months). By increasing the storage times (three months and six months) there was significant increase $(p<0.001)$ in calcium phosphorus ratio $(\mathrm{ca} / \mathrm{p})(2.12 \pm 0.17$ and $2.20 \pm 0.13)$ precipitation to tooth structure.

\section{Diagnodent reading:}

Diagnodent fluorescent reading proved the remineralization to tooth structure for all remineralizing agents (Curodont repair, chitosan and Nanohydroxyapatite paste) and also control group was increased by increasing the storage time (three month and six months).

The highest degree of remineralization recorded by Diagnodent fluorescent reading $(6.80 \pm 1.03)$ was for samples treated by Curodont repair after sixmonth storage time.

While the lowest degree was recorded for the base line samples with Nanohydroxyapatite paste remineralizing agent $(19.40 \pm 1.35)$.

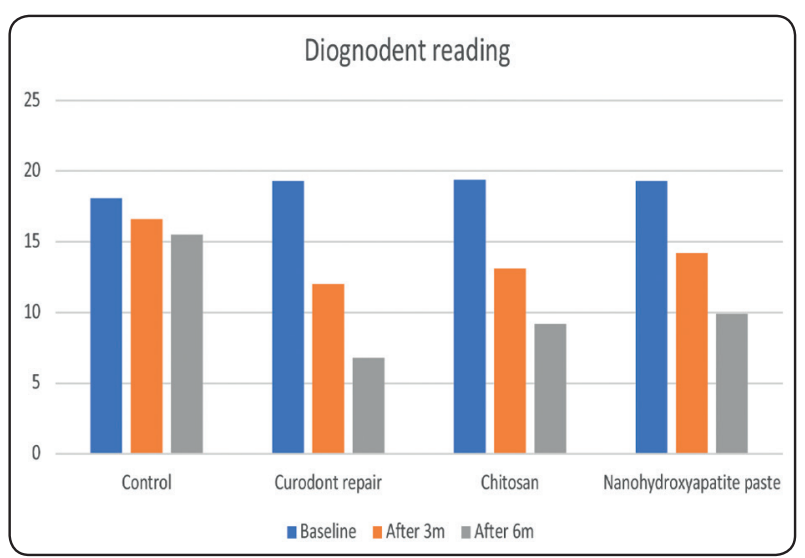

Table (6): The mean, standard deviation (SD) values of Diagnodent reading of different remineralizing agents on mineral precipitation at different storage time.

\begin{tabular}{|c|c|c|c|c|c|c|c|}
\hline \multirow{3}{*}{ Variables } & \multicolumn{7}{|c|}{ Diagnodent } \\
\hline & \multicolumn{2}{|c|}{ Baseline } & \multicolumn{2}{|c|}{ After 3m } & \multicolumn{2}{|c|}{ After 6m } & \multirow[t]{2}{*}{ p-value } \\
\hline & Mean & SD & Mean & SD & Mean & SD & \\
\hline Control & $18.10^{\mathrm{a}}$ & 2.47 & $16.60^{\mathrm{b}}$ & 2.27 & $15.50^{\mathrm{c}}$ & 2.92 & $<0.001 *$ \\
\hline Curodont repair & $19.30^{\mathrm{a}}$ & 1.34 & $12.00^{\mathrm{b}}$ & 1.49 & $6.80^{\mathrm{c}}$ & 1.03 & $<0.001 *$ \\
\hline Chitosan & $19.40^{\mathrm{a}}$ & 1.35 & $13.10^{\mathrm{b}}$ & 1.37 & $9.20^{\mathrm{c}}$ & 0.79 & $<0.001 *$ \\
\hline Nanohydroxyapatite paste & $19.30^{\mathrm{a}}$ & 1.83 & $14.20^{\mathrm{b}}$ & 1.03 & $9.90^{c}$ & 1.20 & $<0.001 *$ \\
\hline p-value & \multicolumn{2}{|c|}{$<0.001 *$} & \multicolumn{2}{|c|}{$<0.001 *$} & \multicolumn{2}{|c|}{$<0.001 *$} & \\
\hline
\end{tabular}

Means with different letters in same raw indicate significant difference $(p<0.05)$ 


\section{DISCUSSION}

Early enamel caries which are called as the White Spot Lesions (WSL) or incipient lesions which can histologically be described as a subsurface carious lesion of the enamel. Noticeable feature being a subsurface demineralized zone with intact and also unharmed enamel surface. Despite of the surface is unblemished, the mineral substance is deficient, when compared to sound enamel. ${ }^{(14)}$

Dental hard tissues are continuously undergoing cycles of demineralization as a consequence of $\mathrm{pH}$ drop of oral cavity and remineralization as a result of a $\mathrm{pH}$ rise leads to deposition of calcium, phosphate and fluoride. The advancement of dental caries occurred when the demineralization exceeds remineralization. ${ }^{(15)}$

The sub surface porosity caused by demineralization gives the lesion a milky appearance that can be found on the smooth surfaces of teeth so, are called white spot lesion. ${ }^{(16)}$

The growing aim of recent dentistry is to handle nonactivated carious lesions noninvasively through remineralization with an end goal to prevent lesion progress, enhance strength, esthetics and function of the teeth. A critical element fundamental to this therapeutic philosophy is the need for new and highly efficacious technologies for enamel remineralization, which resulted in the evolution of various contemporary remineralizing agents. ${ }^{(17)}$

The findings indicated that all three treatment regimens significantly promoted the remineralization of enamel lesions compared to artificial saliva. The highest mean value was found in self-assembling peptide followed by phosphorylated Chitosan (Pchi) and Nanohydroxyapatite paste, while the lowest mean was found in artificial saliva. However, no statistically significant difference was found between phosphorylated Chitosan (Pchi) and Nanohydroxyapatite paste.

Self-assembling peptides showed the highest remineralizing efficacy that it is useful in the modulation to induce hydroxyapatite nucleation, leading to the re-mineralization of white spot lesions through its diffusion into mineral loss and enhancement of hydroxyapatite precipitation which is attributed to the fact that $\mathrm{P}_{11}-4$ is a rationally designed self-assembling peptide that undergoes, in response to specific environmental factors, a hierarchically predetermined process of selfassembly forming three-dimensional fibrillar scaffolds. Once assembled, these scaffolds serve as ideal templates for hydroxyapatite nucleation promoting guided enamel regeneration. ${ }^{(18,19,20)}$

At neutral $\mathrm{pH}, \mathrm{P}_{11}-4$ exists in a low viscosity, liquid monomeric form. When the $\mathrm{pH}$ is decreased $(\mathrm{pH}<7.4), \mathrm{P}_{11}-4$ changes into bioactive gel scaffolds that binds to tooth surface inducing de novo hydroxyapatite crystallization.

$\mathrm{P}_{11}-4$ spontaneously switches and self-assembles to an elastomeric nematic 3D gels that show high affinity to tooth mineral, based on matching distances of Ca-binding sites on $\mathrm{P}_{11}-4$ and $\mathrm{Ca}$ spacing in the crystal lattice of hydroxyapatite. (18,21) This was confirmed by a study conducted by Kirkham et $a l^{(18)}$. where the incubation of $\mathrm{P}_{11}-4$ in mineralizing solutions for 7 days resulted in the presence of needle-like electron-dense deposits within the scaffold itself, suggested to be crystalline hydroxyapatite.

The results obtained in this study are in agreement with studies done by Kirkham et al., Brunton et al., Schmidlin et al., Takahashi et al., Bröseler et al., Schlee et al. and Ceci et al. where they also found $\mathrm{P}_{11}-4$ able to induce biomimetic regeneration of early caries lesions. . $^{(18,5,19,20,21,22,23)}$.

The net remineralization gain produced by artificial saliva was small and a slow process, due to the low ion concentration gradient from saliva into the lesion, precipitating only superficially and preventing the remineralization process from occurring in the body of the lesion ${ }^{(25)}$. Thus, the control group showed the least values of remineralization as saliva fails to initiate the process 
of increasing the levels of calcium and phosphate delivery compared to the remineralizing regimens applied $^{(26)}$. which goes in accordance with studies done by Zhang et al. and Somani et al ${ }^{(26,27)}$ In addition, the formula of the artificial saliva used in the present study did not contain any fluoride which could explain the limited remineralization by the control group. $\left({ }^{24,25}\right)$

The net remineralization gain produced no statistically significant difference was found between phosphorylated Chitosan (Pchi) and Nanohydroxyapatite paste, a $n$ explanation of these interesting findings may be that chitosan acts as a template in the biomineralization process and controls the mineral crystallites through the molecular interaction between the polymer and minerals. The ion or cluster binding in the biomimetic mineralization system assembles into amorphous primary particles at the organic surface, and then the amorphous primary particles build up and form the oriented crystallization. ${ }^{(26)}$ Chitosan not only provided a substrate to immobilize the nano-building units but also acted as a template for the structured assembly of the regenerated enamel layer. ${ }^{(27)}$

The remineralization process is linked to the ability of the biomimetic hydroxyapatite to integrate completely within the enamel structure, such as physiological hydroxyapatite. This product is characterized by high concentration $(30 \%)$ of micro repair (nano-hydroxy apatite crystals), more than other equivalent products, and absence of fluoride, SLS, silica abrasives, titanium dioxide, and parabens. Moreover, this product has the ability to repair enamel microscale specimens protecting from hypersensitivity, erosions, wear, and caries. ${ }^{(28)}$

Biomimetic nano-hydroxyapatite is synthesized in a bulk $\mathrm{Ca} / \mathrm{P}$ molar ratio of 1.7 . Moreover, it contains about $4 \pm 1$ wt $\%$ of carbonate ions. These ions replace especially phosphate groups. Biomimetic carbonate-hydroxyapatite nanocrystals can aggregate in clusters. These aggregates present a nanostructured surface area of about $80 \mathrm{~m} 2 / \mathrm{g}$.
These crystals have been Reported to be used in toothpastes and mouthwashes as mineralized agents. ${ }^{(29,30)}$

Regarding the storage period of this study, the results revealed that the remineralization potential of all the tested materials increased significantly over time. Higher values were obtained after 6 months with a significant difference between 3 months and 6 monthes measurements, which is in accordance with studies done by Elkassas and Arafa, Oliveira et $a l$. and Vyavhare et $a .{ }^{(24,31)} r$ emineralizing therapies act either by releasing or by attracting calcium and phosphate ions that will penetrate the demineralized surface, initiating a regeneration process of ion deposition into crystal voids with subsequent crystal growth rebuilding the lost hydroxyapatite latticework structure. This denotes that remineralization is a time-dependent process.

\section{CONCLUSION}

Under the limitations of the present study, it can be concluded that Curodont repair is considered a valuable biomimetic remineralizing agent and confers the highest remineralizing efficacy compared to phosphorylated chitosan and nanohydroxyapatite paste. Furthermore, mineral precipitation to tooth structures by using remineralizing agents is a continuous dynamic process.

\section{REFERENCES}

1. Pretty IA, Ellwood RP. The caries continuum: Opportunities to detect, treat and monitor the remineralization of early caries lesions. J Dent. 2013;41(Suppl 2): S12-21.

2. Amaechi BT. Remineralization therapies for initial caries lesions. Curr Oral Health Rep. 2015; 2:95-101.

3. Goswami S. Remineralize early demineralized enamel structure. SRM Journal of Research Dental Sciences. 2016 Oct $1 ; 7(4): 231-234$.

4. Divyapriya GK, Yavagal PC, Veeresh DJ. Casein phosphopeptide-amorphous calcium phosphate in dentistry: An update. Int J Oral Health Sci 2016; 6(1):18-25. 
5. Brunton PA, Davies RP, Burke JL, Smith A, Aggeli A, Brookes SJ, et al. Treatment of early caries lesions using biomimetic self-assembling peptides - a clinical safety trial. Br Dent J. 2013;215: E6.

6. Ceci M, Mirando M, Beltrami R, Chiesa M, Colombo M, and Poggio C. Effect of self-assembling peptide P11-4 on enamel erosion: AFM and SEM studies. Scanning Vol. 2016; 38: 344-351.

7. Brubaker L, Vinh A, Patel S, Solomon E, Amaechi B, and Noureldin A. Remineralization of early-enamel lesions using biomimetic regeneration combined with fluoride toothpaste. Br Dent J 2015; 2-10.

8. Husain S, Al-Samadani KH, Najeeb S, Zafar MS, Khurshid Z, Zohaib S, et al. Chitosan Biomaterials for Current and Potential Dental Applications. Materials (Basel). 2017 Jun; 10(6): 602.

9. Jay S, Dutta PK. Preparation, antibacterial and physicochemical behavior of chitosan/ofloxacin complexes. Int J Polym Mater. 2010; 59:793-807.

10. Gebauer D, Colfen H. Prenucleation clusters and non-classical nucleation. Nano Today. 2011;6(6):564-84.

11. Jayashankara C.M.,John, Jyothi Kashi Nanjunda setty, Paluvary Sharath Kumar and Girish, S.A.comparative evaluation of shy-nm and remin pro on the microhardness of bleached enamel: an in vitro study. International Journal of Information Research and Review 2016 Vol. 03, Issue, 12, pp. 3464-3468.

12. Rezvani M, Atai M,3 Rouhollahi M, Malekhoseini K, Rezai H, and Hamze F: Effect of Nano-Tricalcium Phosphate and Nanohydroxyapatite on the Staining Susceptibility of Bleached Enamel.International Scholarly Research Notices 2015 Article ID 935264, 1-7.

13. Gomes YSBL, Alexandrino LD, Alencar CDM, Alves EB, Faial KCF, Silva CM. In situ Effect of Nanohydroxyapatite Paste in Enamel Teeth Bleaching. J Contemp Dent Pract 2017;18(11):996-1003.

14. Lata S, Varghese NO, Varughese JM. Remineralization potential of fluoride and amorphous calcium phosphatecasein phospho peptide on enamel lesions: An in vitro comparative evaluation. Journal of conservative dentistry: Journal of conservative dentistry $2010 \mathrm{Jan} ; 13(1): 42-4$.

15. Nagarathana C, Sakunthala BK, and Naveena Preethi P. An Update on Current Remineralizing Agent. OHDM 2015; 14: 183-187.
16. AlShehri A and Kwon S.R. Etiology and management of white spot lesions. Prosthetics Restorative. J Multidiscipl Care, Decisions in Dentistry January 1, 2016: 10-19.

17. Amaechi BT. Remineralization therapies for initial caries lesions. Curr Oral Health Rep. 2015; 2:95-101.

18. Kirkham J, Firth A, Vernals D, Boden N, Robinson C, Shore RC, et al. Self-assembling peptide scaffolds promote enamel remineralization. J Dent Res. 2007; 86:426-30.

19. Schmidlin P, Zobrist K, Attin T, Wegehaupt F. In vitro rehardening of artificial enamel carieslesions using enamel matrix proteins or self-assembling peptides. J Appl Oral Sci. 2016; 24:31-6.

20. Takahashi F, Kurokawa H, Shibasaki S, Kawamoto R, Murayama R, Miyazaki M. Ultrasonic assessment of the effects of self-assembling peptide scaffolds on preventing enamel demineralization. Acta Odontol Scand. 2016; 74:142-7.

21. Brseler F, Tiemann C, Schleich R, Drechsel T, Bommer C. Effect of Curodont ${ }^{\mathrm{TM}}$ repair in patients with buccal carious lesions: A mono-center, single-blinded, randomized, controlled, split-mouth study-intermediate report. Clin Oral Investig. 2013; 17:1055.

22. Schlee M, Rathe F, Bommer C. Effect of Curodont TM repair in patients with proximal carious lesions: Uncontrolled, non-interventional study-interim report. Clin Oral Investig. 2013; 17:1046-7.

23. Ceci M, Mirando M, Beltrami R, Chiesa M, Colombo M, Poggio C. Effect of self-assembling peptide P11 -4 on enamel erosion: AFM and SEM studies. Scanning. 2016; 38:344-51.

24. Elkassas D, Arafa A. Remineralizing efficacy of different calcium-phosphate and fluoride-based delivery vehicles on artificial caries like enamel lesions. J Dent. 2014; 42:466-74.

25. Memarpour M, Fakhraei E, Dadaein S, Vossoughi M. Efficacy of fluoride varnish and casein phosphopeptide-amorphous calcium phosphate for remineralization of primary teeth: A randomized clinical trial. Med Princ Pract. 2015; 24:231-7.

26. Cao CY, Mei ML, Li QL, Lo EC, Chu CH. Methods for biomimetic remineralization of human dentine: A systematic review. Int J Mol Sci. 2015; 16:4615-27.

27. Somani R, Jaidka S, Singh DJ, Arora V. Remineralizing potential of various agents on dental erosion. J Oral Biol Craniofac Res. 2014; 4:104-8. 
28. M. Lelli, O. Marchisio, I. Foltran et al. Different corrosive effects on hydroxyapatite nanocrystals and amine fluoride-based mouthwashes on dental titanium brackets: a comparative in vitro study," International Journal of Nanomedicine, vol. 8, no. 1, pp. 307-314, 2013.

29. M.Lelli,A.Putignano,M.Marchettietal.,"Remineralization and repair of enamel surface by biomimetic Zn-carbonate hydroxyapatite containing toothpaste: a comparative in vivo study," Frontiers in Physiology, vol. 5, p. 333, 2014.

30. Jayasudha, Baswaraj, Navin H.K, and Prasanna K.B. Enamel Regeneration - Current Progress and Challenges. J Clin Diagn Res 2014; 8: ZE06-ZE09.

31. Vyavhare S, Sharma DS, Kulkarni VK. Effect of three different pastes on remineralization of initial enamel lesion: An in vitro study. J Clin Pediatr Dent. 2015; 39:149-60. 